\title{
Legality of Restrictions on Human Rights in a State of Military Emergency in Indonesia
}

Muliadi ${ }^{1 *}$, A. Muin Fahmal ${ }^{2}$, Muhammad Syarief $\mathrm{Nuh}^{3}$, and Hamzah Baharuddin ${ }^{4}$

${ }^{7}$ Doctoral Candidates, Universitas Muslim Indonesia

${ }^{2}$ Professor of the Faculty of Law, Universitas Muslim Indonesia

${ }^{3}$ Lecturer in Constitutional Law, Faculty of Law, Universitas Muslim Indonesia

${ }^{4}$ Lecturer in Constitutional Law, Faculty of Law, Universitas Muslim Indonesia

Corresponding Author: Author's Name,Muliadi E-mail: muliadirusmana87@gmail.com

\section{ARTICLE INFO}

Received: November 02, 2020

Accepted: December 25, 2020

Volume: 3

Issue: 1

DOI: 10.32996/jhsss.2021.3.1.1 KEYWORDS

Legality; Restrictions Human

Rights; State of Military

Emergency; Indonesia

\section{ABSTRACT}

This study aims to look at the legality of human rights restrictions in a military emergency in Indonesia. This research uses a normative legal research type. The choice of this type of normative analysis is related to the formulation of problems that become legal research issues. The findings of this study are that restrictions on human rights in a state of military emergency are justified because the human rights possessed by every human being do not apply, primarily if an army emergency is enforced, all human rights possessed by every human being can be limited to the implementation for the respect of human rights, the enforcement of a military emergency must see the condition of a region whether it is categorized as threatening the life of the nation or not. For this reason, this study recommends that the Government, in imposing restrictions on human rights in a military emergency, must be based on the element of a dangerous threat.

\section{Introduction}

An emergency has many terms that are used in practice in various countries regarding a state that is meant by an emergency; for example, France calls a crisis as "etat de siede", America and Britain call it "Martial Law", international human rights instruments such as the European Convention on Human Rights (European Convention on Human Rights), American Convention on Human Rights (American Convention on Human Rights) and International Covenant on Civil and Political Rights (International Covenant on civil and political rights) use the term 'public emergency' (Addo, 2017), India calls it "emergency of law, Canada" war measure act, while Indonesia calls it a state of danger as mentioned in Article 12 of the 1945 Constitution of the Republic of Indonesia which states that "the President declared a state of danger. The conditions and consequences for the situation of danger are determined by law". In the context of elaborating Article 12 of the 1945 Constitution of the Republic of Indonesia as mentioned above, the particular law is the Government Regulation instead of Law Number 23 of 1959 concerning the Stipulation of Hazards. A state of danger is a situation that suddenly threatens a general order, which requires the state to act in ways that are not customary according to the rules of law that usually apply in normal conditions (Mar \& Tamanaha, 2018).

In normal circumstances, the legal norms system is enforced based on the 1945 Constitution of the Republic of Indonesia and statutory instruments that are officially established to regulate various aspects relating to the implementation of state activities in general. However, suppose the state is in a state of emergency. In that case, the legal system must use powers and procedures that are emergency through emergency law that can override customary state laws, without influencing democratic government systems adopted based on the constitution (Gultom, 2013). Carl Schitt, who emerged as a German jurist, advocated for the idea that "laws which apply under normal circumstances can be overridden or postponed, replaced by emergencies imposed by President.

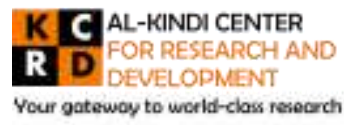

Published by Al-Kindi Center for Research and Development. Copyright (c) the author(s). This is an open access article under CC BY license (https://creativecommons.org/licenses/by/4.0/) 
The same thing was also explained by Beni Prasad that "In an emergency, the government is considered to be able to take any action. The justification for this is based on the understanding that an abnormal situation has its system of legal and ethical norms, or a situation called Appaddharma, which means a very dire crisis. In this abnormal situation, all the rules of morality that normally apply in normal circumstances can be postponed" (Prasad, 1968).

In Indonesia, a state of emergency with a state of war emergency was implemented in the 1950s during the Old Order era, which was enforced through Presidential Decree 225 of 1957, which was later ratified by Law Number 79 of 1957, which was later amended by Government Regulation in place of Law Number 23 of 1959 concerning the Determination of Danger Conditions. Then at the civil emergency level, it has also been stipulated to overcome riots carried out in Maluku and North Maluku through Presidential Decree No. 88 of 2000 concerning Civil Emergencies in Maluku Province and North Maluku Province as amended by Presidential Decree No. 40 of 2002.

The riots that occurred in Maluku and North Maluku were horizontal. Particularly for the state of military emergency, it has been implemented several times in Indonesia, starting in 1999 during the transition of the New Order government to the reform era, where East Timor was voting for the consequences of a referendum, General TNI Wiranto proposed to President Habibie to establish a military emergency status responding to the unrest that occurred during the referendum. However, the Indonesian cabinet refused to determine the military emergency proposed by TNI General Wiranto on September 6, 1999, after meeting face to face the next day. President BJ. Habibie issued Presidential Decree No. 107/1999 concerning the stipulation of martial law in East Timor, which Major General Kiki Syahnakri, which seemed sudden and ineffective, resulting in violations of human rights. Likewise, during President Megawati Soekarno Putri's reign in 2003, which imposed a state of military emergency in the Province of Nangroe Aceh Darussalam to face the resistance movement calling itself the "Free Aceh Movement (GAM)". During the enactment of the military emergency, the military emergency authorities have the right or authority to impose restrictions on human rights (Matompo, 2014).

The provisions on human rights restrictions in a military emergency are a further elaboration of the provisions of Article 12 and Article 28J paragraph (2) of the 1945 Constitution of the Republic of Indonesia, which are the closing provisions of all conditions regulating human rights, which state that: "In exercising his rights and freedoms, every people are obliged to comply with the restrictive provisions stipulated by law with the sole purpose of ensuring recognition and respect for the rights and freedoms of others and to fulfill fair demands by considerations of moral, religious values, security and public order in a democratic society."

Observing the provisions on human rights restrictions above, it will appear that, systematically, human rights are not absolute, so that in the framework of "fulfilling fair demands by moral considerations, religious values, security, and order," their fulfillment can be limited, especially if the State in a military emergency. This is, of course, contrary to the provisions of Article 28I paragraph (1) of the 1945 Constitution of the Republic of Indonesia, where this provision prohibits restrictions on human rights that are nonderogable rights (human rights that cannot be limited in any circumstances). Human rights, which are non-derogable rights, are one of the human rights that are enforceable in any situation, including in a military emergency, especially the words "cannot be reduced under any circumstances" are words that are clear and clear, or by borrowing the term, Islamic figh law is a qoth'i argument. Suppose Article 28J paragraph (2) of the 1945 Constitution of the Republic of Indonesia can be interpreted as reducing and limiting human rights that are non-derogable rights recognized in Article $28 \mathrm{I}$ paragraph (1) of the $1945 \mathrm{NRI}$ Constitution. What is the use of the specialization that has been made of rights that are of nature nondelegable right in the 1945 Constitution of the Republic of Indonesia, if in the implementation of the military emergency it is justified to impose restrictions on these human rights?

\section{Methodology}

This research uses a normative legal research type. The choice of this type of normative analysis is related to the formulation of problems that become legal research issues. This type of normative legal research is also used to study/analyze secondary data in standard materials, mainly traditional primary materials and secondary legal materials.

\section{Results and Discussion}

A state of emergency is a situation of great crisis or emergency that affects the entire population. It is a threat to the organized nation's life with which the country is constituted. According to Thomas Buergenthal, an emergency must be emphasized; it does not need to hit or will hit the entire nation to be said to be "threatening the life of the nation." General emergencies that threaten the government's life can occur even though the troubles that arise are limited to one part of a country, for example, one country territory, and do not have the potential to spread to other parts of the country (Buergenthal et al., 2009). 
Like the military emergency that has been implemented several times in several regions in Indonesia, namely starting in 1999 during the transition of the New Order government to the reform era, where East Timor was voting for the consequences of a referendum, General TNI Wiranto proposed to President Habibie to establish one martial law in response to the unrest that occurred during the referendum. However, the Indonesian cabinet refused to determine the military emergency proposed by TNI General Wiranto on September 6, 1999, after meeting face to face the next day.

President BJ. Habibie issued Presidential Decree No. 107/1999 concerning the establishment of martial law in East Timor, led by Major General Kiki Syahnakri. Likewise, during the reign of President Megawati Soekarno Putri in 2003, which imposed a state of military emergency in the Province of Nangroe Aceh Darussalam to face the resistance movement calling itself the "Free Aceh Movement (GAM)" which was later outlined in the form of Presidential Decree No. 28 of 2003 concerning the Statement of Danger with the Level of Military Emergency in the Province of Nanggroe Aceh Darussalam and the Presidential Decree of the Republic of Indonesia Number 97 of 2003 concerning the Statement of Extending the State of the Danger with the Level of Military Emergency in the Province of Nangroe Aceh Darussalam.

According to researchers, the elements of an emergency mentioned above do not apply to all countries in the world because each country has different characteristics, and the understanding of an emergency is further in each country. So that indirectly, the cause of a crisis in a country will be other. It is appropriate to determine whether the State is in a state of emergency or not fully surrendered to the State. This is based on the doctrine of necessity, namely the principle of need, which recognizes every sovereign State's right to take the necessary steps to protect and maintain the integrity of the State.

According to researchers, this doctrine of necessity is contained and formulated in Article 4 (1) of the ICCPR, which briefly states when the State is in a state of emergency that threatens the life of the nation, which has been officially announced by the state party can take steps to reduce its obligations to the extent necessary in the situation. This means that when there are no other peaceful alternative steps available and useful to overcome the emergency, then a crisis will be enforced based on the principle of necessity. The nature of the trouble is prevention and not a punishment for the community; the aim is to return the State to normalcy.

After fulfilling the elements of an emergency above, according to $C$. De Rover, the next procedure is that the State party must officially declare that the State is in a state of emergency. This declaration of emergency lies the essential meaning: the population must know the material, area, and scope of time-implementation of the emergency measure and its impact on human rights performance.

Many state constitutions in the world make emergency clauses that give the head of State the power to proclaim (declare) his country de jure in a state of emergency. For example, the fifth republic constitution in France explicitly gives the President the authority to unilaterally declare or declare a state of emergency (etat de siege) (Kreis, 1981).

In a state of emergency that threatens the nation's life, the constitution gives power to the President's head to judge whether the country is in a severe condition or not based on the TNI Commander and the minister's report of Defense and Security. It can be claimed that only the government has the responsibility to protect the nation's life and use the necessary information as a consideration to declare the State in a state of emergency. In the opinion of the researcher, the need for the announcement is primarily intended as legitimacy and legality for the apparatus, in this case, the TNI / Polri, to take the necessary actions to return the State to normalcy and provide convenience to the international community to control the enforcement of this emergency.

The necessary actions must be based on the principle of proportionality (reasonable) or in kind, meaning that the said action must not exceed the reasonableness which becomes the justification for the act itself, to defend oneself (self-defense) threats that endanger the life of the nation. The declaration of the entry into force of this emergency must be by the intensity of hazards that can threaten the life of the community or the survival of the nation and State and territorial integrity and national unity and integrity and its implementation shall be regulated by law.

The House of Representatives (DPR), as the supervisory agency for the running of the wheels of government in the framework of implementing laws, is interested in enacting this emergency so that the statement or declaration of the enforcement of the crisis must be notified to the DPR. Apart from being administrative, notification to the DPR is also submitted to request approval for the emergency's enforcement. Besides needing to be written in the form of a Law or Presidential Decree, the legal text for the enforcement of an emergency must also be submitted to the parties concerned according to national law and international law requirements. 
As for the related parties that must be conveyed when the emergency is in the form of a Law or Presidential Decree, according to the provisions of national law are all relevant state institutions through their respective leaders, such as the House of Representatives (DPR); Regional Representative Council (DPD), People's Consultative Assembly (MPR), Constitutional Court (MK), Supreme Court (MA), Supreme Audit Agency (BPK), Indonesian National Army (TNI), Indonesian National Police, Attorney General's Office, Bank Indonesia, Cabinet Ministers and Regional Heads (Governors, Regents, or Mayors) whose areas are subject to a state of emergency. Meanwhile, according to international law provisions itself, the crisis must be notified to friendly countries (neighboring countries) and other parties to the relevant agreement.

Notification must be submitted formally through the representatives of the countries concerned through the United Nations Special Rapporteur regarding emergencies as regulated in the 1503 Procedure, namely the Special Rapporteur on the Question of Human Rights and states of trouble which is commonly known by the abbreviation, "Special Rapporteur on States of Emergency (Fitzpatrick, 1994).

The enactment of a state of emergency must be limited by time, which requires certainty when an emergency begins and ends or ends, this is to avoid the abuse of power that can threaten freedom and human rights guarantees, and the abolition of an emergency is carried out by the President and outlined in the form (Perpu) or the form (Kepres) (Jayawickrama, 2002).

When the State is legitimate in the sense that it has legally declared a state of emergency with the level of military crisis, then human rights in an army emergency are divided into two groups, namely, first, human rights are included in the Derogable rights category (human rights that can be limited in any situation), second Human rights are included in the non-derogable rights category (human rights that the fulfillment of which cannot be determined under any circumstances). To separate the two groups of human rights in a military emergency, the researcher used Muin Fahmal's opinion, which explained that human rights are inherent rights of humans that are inherited from birth as a gift from God Almighty, which is natural in that if this is violated, the human essence of humanity is not perfect.

Apart from the 15 (fifteen) human rights stipulated in the 1945 Constitution of the Republic of Indonesia, their fulfillment can be limited until the state returns to normal. This means that the state's restrictive measures can legally be justified, provided that the state is in a state of danger due to rebellion or armed threats from certain groups that threaten the life of the community. Besides that, the president has declared the emergency as head of state to the public transparently. The restrictive measures taken must be proportional (reasonable) or equal, meaning that the said action must not exceed the reasonableness which becomes the justification for the act itself, because the purpose of determining the status of an emergency in an area is not to kill but to disarm. And paralyze the opponent or enemy so that things return to normal.

To determine the actions taken or taken by the military emergency authorities fulfill the principle of proportionality, the researcher used Muin Fahmal's opinion that the story was said to be proportional if the actions of the apparatus were carried out by Standard Operating Procedures (SOP) when the war was not balanced if the actions taken by the military emergency apparatus or authorities were not by the applicable SOP (Adhari, 2019).

Based on developments, there have been differences in views regarding the application of human rights in a military emergency; on the one hand, there is a view that human rights are not absolute, but on the other hand, human rights are fundamental. One of the opinions that says human rights are absolute is Jimly Asshiddiqie, who says that "even though the state has a state of emergency war or other circumstances, the seven human rights regulated in Article 28l paragraph (1) apply" absolutely "even though only at the absolute human level. What is meant by human absolute is that its fundamental character applies as long as the constitutional formulation itself, which is the product of the highest social agreement, is not changed again at one point in time?

This means that the absolute nature of the binding of the highest constitutional law's legal norms remains relative as well. Jimmy Asshiddiqie further said that the normative constitutional construction of human rights, which cannot be reduced under any circumstances, can be justified juridically-philosophically because if the seven human rights can be limited their enforcement by the provisions of Article 28J paragraph (2) of the 1945 Constitution of the Republic of Indonesia, The explicit provision of Article 28 I paragraph (1) of the 1945 Constitution of the Republic of Indonesia states that "the seven rights cannot be limited under any circumstances." 
Jimmy Asshiddiqie added that the limitation referred to in Article 28J paragraph (2) of the 1945 NRI Constitution does not address the provisions of Article 28I paragraph (1) of the $1945 \mathrm{NRI}$ Constitution. 28A through Article 28H. The same opinion was also explained by Laica Marzuki, who said that with the inclusion of the principle (which cannot be limited) in Article 28I of the 1945 NRI Constitution, Article 28I of the 1945 NRI Constitution could not be negated by Article 28J of the 1945 NRI Constitution which only stipulates restrictions. The use of everyone's rights and freedoms based on a law in the meaning of wet, Gesetz, but not at all in the sense of limitation based on Grundgesetz (fundamental law).

Mukthie Fajar further argues that Article 28J paragraph (2) limitation can only be applied to rights that have not been/are not limitedly regulated under Article 28I paragraph (1). He argued that the right to life, the right not to be tortured, the right to freedom of thought and conscience, the right to religion, the right not to be enslaved, the right to be recognized as a person before the law, and the right not to be prosecuted based on retroactive law is human rights. which cannot be reduced under any circumstances and by anyone (Van Diermen, 2000).

These rights are regulated not only in Article 28I paragraph (1) of the 1945 Constitution of the Republic of Indonesia but also regulated in Article 7 of MPR Decree No. XVII / MPR / 1998 concerning Human Rights and Article 4 of Law Number 39 the Year 1999 concerning Human Rights. In other words, the only restrictions allowed are those that are categorized as derogable rights and not those that are classified as non-derogable rights.

The researcher agrees with the two experts above because if we draw from the original intent of the formation of the 1945 NRI Constitution, all human rights listed in Chapter XA of the 1945 NRI Constitution can be limited in effect. The original intent of the NRI 1945 Constitution, which stated that human rights could be restricted, was also strengthened by the placement of Article 28J as the closing article of all provisions regulating human rights in Chapter XA of the 1945 Constitution. Citing the legal considerations of the Constitutional Court in case Number 23 / PUU-V / 2007, then in a systematic interpretation (systematic interpretation), the human rights regulated in Article 28A to Article 28I of the 1945 Constitution of the Republic of Indonesia are subject to the restrictions stipulated in Article 28J. The 1945 Constitution of the Republic of Indonesia.

In line with Indonesia's constitutionalism view of human rights as described above, when the MPR Decree Number XVII / MPR / 1998 on Human Rights was issued, which was further elaborated in Law Number 39 of 1999 concerning Human Rights, these two legal products appeared as a continuation and at the same time an affirmation that the view of Indonesian constitutionalism has not changed because it turns out that both also contain restrictions on human rights.

Based on the description above, the researcher concludes that the human rights possessed by every human being do not apply, primarily if a military emergency is enforced, all the human rights possessed by every human being can be limited to the implementation for the respect of human rights towards others as well because if human rights are not restricted in an emergency, then there will be arbitrary actions which in the end will be anarchic and will cause ongoing dangers and of course will affect the integrity of the country.

The provisions of Article 28J of the $1945 \mathrm{NRI}$ Constitution make the provisions of Article 28I paragraph (1) of the $1945 \mathrm{NRI}$ Constitution weak or of a relative nature. According to Article 28J, everyone (without exception) is obliged to respect others' human rights. So, in terms of exercising their rights and freedoms, everyone is obliged to comply with law restrictions. This is reinforced by the provision of Article 28 I paragraph (5) of the 1945 Constitution of the Republic of Indonesia, which reads, "To uphold and protect human rights in accordance with the principles of a democratic rule of action of human rights is guaranteed, regulated and contained in statutory regulations.".

This means that in normal or normal circumstances, the provisions on human rights can be limited by law, especially in a military emergency, if the authorities, in this case, the President, have formally established a norm of enforcing a state of emergency in an area where there is a conflict, then every citizen must comply with and obey the contents of the standards of the military crisis. This needs to be taken into account to fulfill fair demands based on moral, religious, security, and public order considerations.

To further strengthen the researcher's argument that human rights can be limited, especially when a region has declared a state of military emergency, the researcher quotes a verse from the Koran in Surah Al-Baqarah verse 173, which means: "actually he only forbids corpses, blood, flesh. Pigs, and (meat) animals that were slaughtered by (mentioning names) other than Allah. But whoever is forced to (eat it), not because he wants it and does not (also) exceed the limit, then there is no sin for him, truly Allah is allforgiving, most merciful". In the principle of a good fight or Islamic legal philosophy, there is a doctrine of "al-dharuuraatu tubiihu al-mahzhuurat" which means that an emergency allows things that are prohibited. This means that if an emergency is enforced, items that are not permitted may become permissible, while things that were allowed may become banned. 
Based on the preceding, if it is related to the government's actions to limit human rights in a military emergency, these unusual actions are certainly justified due to an emergency, if the government does not take restrictive measures on human rights, of course, security stability is out of control so that based on an emergency, something that is not justified to be done as said by Allah SWT above can be justified to be carried out as long as the restrictive measures are proportional (reasonable/appropriate) to defend oneself from the threat of danger faced by the State.

\section{Conclusion}

This research concludes that restrictions on human rights in a military emergency are justified because the human rights possessed by every human being do not apply, primarily if an army emergency is enforced, all human rights possessed by every human being can be limited to the implementation for the respect of people's human rights, the performance of a military emergency must see the condition of a region, whether it is categorized as threatening the life of the nation or not, after that the president declared a state of military emergency to become legitimate for the military emergency authorities to take the necessary actions to restore the state's condition to normal. In imposing restrictions on human rights in a state of military emergency, the government should be based on elements of dangerous threats, parts that require it, and aspects of time limitations. The policy of enforcing human rights restrictions can be justified to be implemented.

\section{References}

[1] Addo, M. (2017). International law of human rights. Routledge.

[2] Adhari, A. (2019). Ambiguitas Pengaturan Keadaan Bahaya Dalam Sistem Ketatanegaraan Indonesia. Dialogia luridica: Jurnal Hukum Bisnis Dan Investasi, 11(1), 43-61.

[3] Buergenthal, T., Shelton, D. L., \& Stewart, D. P. (2009). International human rights in a nutshell. Thomas Buergenthal, Dinah Shelton \& David P. Stewart, INTERNATIONAL HUMAN RIGHTS IN A NUTSHELL (4th), 2013-2034.

[4] Fitzpatrick, J. (1994). Human rights in crisis: the international system for protecting rights during states of emergency (Vol. 19). University of Pennsylvania Press.

[5] Gultom, B. (2013). Pelanggaran HAM Dalam Hukum Keadaan Darurat Di Indonesia. Gramedia Pustaka Utama.

[6] Jayawickrama, N. (2002). The judicial application of human rights law: national, regional and international jurisprudence. Cambridge university press.

[7] Kreis, G. (1981). État démocratique en état de siège. Revue d'histoire de La Deuxième Guerre Mondiale, 31(121), 71-82.

[8] Mar, M., \& Tamanaha, B. Z. (2018). Understanding Legal Pluralism: Past to Present, Local to globalt. In Legal Theory and the Social Sciences. https://doi.org/10.4324/9781315091891-17

[9] Matompo, O. S. (2014). Pembatasan Terhadap Hak Asasi Manusia Dalam Prespektif Keadaan Darurat. Media Hukum, 21(1), 16.

[10] Prasad, B. (1968). Theory of Government in Ancient India. Central Book Depot.

[11] Van Diermen, P. (2000). Indonesia di tengah transisi: aspek-aspek sosial reformasi dan krisis. PT LKiS Pelangi Aksara. 